\title{
Fluctuations in Miserotoxin
}

\section{Concentration of Timber Milkvetch on Rangelands in British Columbia}

\author{
W. MAJAK, A. McLEAN, T. P. PRINGLE, AND A. L. VAN RYSWYK
}

Highlight: The variation in miserotoxin concentration (percent dry weight) of timber milkvetch (Astragalus miser var. serotinus) was ascertained for 19 sites throughout British Columbia. Determinations were based on recently developed methods of micro-isolation and derivatization of miserotoxin from fresh-frozen timber milkvetch samples. With the exception of one site, timber milkvetch located in fescue grassland areas yielded the highest miserotoxin values 15.8 to 7.3\%); whereas the lowest peaks (3.1 to 4.3\%) were recorded in the mediumcanopied forests of the Douglasfir-pinegrass community. Subalpine, savannah, parkland, and semiopen areas of the montane forest exhibited intermediate miserotoxin maxima (4.3 to 5.8\%). The data for 1973 suggest that grazing should be avoided in the fescue grasslands in spring and minimized in exposed forest areas.

Miserotoxin (3-nitro-1-propyl-B-Dglucopyranoside) is the poisonous principle that occurs in three varieties of timber milkvetch: Astragalus miser var. hylophilus (Rydb.) Barneby; $A$. miser var. oblongifolius (Rydb.) Cron.; and $A$. miser var. serotinus (Gray) Barneby (Williams and Norris, 1969). These varities are widely separated geographically and the distribution of variety serotinus is limited to northern Washington, British Columbia, and western Alberta (Barneby, 1956; Norris, 1970). Various estimates agree that 2 to $5 \%$ of the rangeland cattle are either chronically or fatally affected by timber milkvetch poisoning in British Columbia (Bruce, 1927; MacDonald, 1952; B. C. Dep. of Agriculture, 1967). The economic losses are magnified by reduced liveweight gains, calf crop losses, and forced

The authors are plant biochemist, ecologist, former research assistant, and pedologist, Research Station, Canada Department of Agriculture, Kamloops, British Columbia.

The authors gratefully acknowledge the cooperation of the following ranchers: $J$. Harfman, J. Koster, C. F. Janzen, H. Allison, A. E. Bracewell, and G. Haywood Farmer. The advice and assistance provided by $A . H$. Bawtree, extension range specialist, British Columbia Department of Agriculture, was greatly appreciated.

The research is Contribution Number 242, Research Station, Canada Department of Agriculture, Kamloops, B.C.

Manuscript received January 5, 1974. shipment of cattle (Nicholson, 1963; B. C. Dep. of Agriculture, 1967).

Stermitz et al. $(1969,1972)$ conducted the original isolation and characterization of miserotoxin from $A$. miser var. oblongifolius and Hahn (1970) reported the purification of the aglycone of miserotoxin, 3-nitro-1propanol, from the same variety. Majak and Bose (1974) have confirmed recently the occurrence and identity of miserotoxin from $A$. miser var. serotinus.

The clinical signs of timber milkvetch poisoning in cattle can be induced by equivalent doses of 3-nitro-1propanol (Williams et al., 1969), the toxic metabolite of miserotoxin which is released in the rumen (Williams et al., 1970). Mosher et al. (1971) demonstrated with sheep that timber milkvetch toxicosis is accompanied by elevated serum glutamate oxaloacetate transaminase activity but that the blood levels of glucose and thiamine were unaffected. Intramuscular injection of thiamine hydrochloride, however, is used therapeutically with limited success in south central British Columbia (Nicholson, 1963).

Researchers have proposed two approaches to timber milkvetch control: Williams (1970) reported that toxicity of timber milkvetch can be reduced by the application of the herbicides Silvex or 2,4,5-T, which depressed the level of miserotoxin by two thirds. Hall and Brink (1971), on the other hand, have advocated the use of nitrogen fertilizers to enhance the competitive growth of grasses producing a concomitant decline in the population of timber milkvetch. The feasibility of these proposals for vast timbered rangelands is, however, questionable.

The present study was conducted to elucidate the toxicity trends of timber milkvetch at 19 representative rangeland sites in British Columbia. Seasonal fluctuations in miserotoxin concentration of the variety serotinus were determined during the spring and summer of 1973 according to the recently developed method of Majak and Bose (1974). Accordingly, the results would contribute toward the formulation of range management guidelines.

\section{Materials and Methods}

\section{Experimental Plots}

Uniform sampling sites, at least 100 $X 200 \mathrm{ft}$, were selected at the various locations in British Columbia described in Table 1 . The soil at each site was classified (Canada Soil Survey Committee, 1970) by inspection and by consultation with soil survey personnel of the B. C. Department of Agriculture, Kelowna. Relative treecanopy covers were estimated as either medium (normally-stocked, montane forest, 20 to $35 \%$ cover), light (semiopen conditions such as parkland or savannah, 0 to $20 \%$ cover), or zero (fescue grassland).

\section{Plant Samples}

Random sampling of timber milkvetch at a given point in time proceeded as follows: the aerial portions of 15 to 20 plants were excised 1 inch 
Table 1. Vegetation classifications and physical features of plots 1 to 19.

\begin{tabular}{|c|c|c|c|c|c|c|c|c|}
\hline Plot no. & Location & Plant zone & Plant community & $\begin{array}{l}\text { Elevation } \\
\text { (ft) }\end{array}$ & Soil order & Exposure & $\begin{array}{c}\text { Slope } \\
(\%)\end{array}$ & Canopy \\
\hline 1 & Lac du Bois & Rough fescue & Rough fescue-eriogonum & 3000 & Chernozem & - & 2 & 0 \\
\hline 2 & Lac du Bois & " & " & 2950 & " & WNW & 45 & 0 \\
\hline 3 & McQueen L. & $"$ & $"$ & 3200 & $"$ & $\mathrm{E}$ & 27 & 0 \\
\hline 4 & McQueen L. & $"$ & $"$ & 3200 & $"$ & SW & 21 & 0 \\
\hline 5 & Pinantan L. & $"$ & $"$ & 3150 & $"$ & SSW & 11 & 0 \\
\hline 6 & Miner Mt. & $"$ & $"$ & 3000 & $"$ & SW & 27 & 0 \\
\hline 7 & Greenstone Mt. & Subalpine fir & Alpine big sagebrush-pinegrass & 5684 & Brunisol & SSW & 38 & $\mathbf{L}$ \\
\hline 8 & Bonaparte R. & Douglasfir & Douglasfir-rough fescue & 3000 & " & $\mathrm{S}$ & 15 & L \\
\hline 9 & Princeton & $"$ & Douglasfir-pinegrass & 2600 & Luvisol & SE & 5 & $\bar{L}$ \\
\hline 10 & Canoe $\mathrm{Cr}$. & $"$ & (") & 3960 & Brunisol & $\mathrm{W}$ & 13 & $\mathbf{L}$ \\
\hline 11 & Leighton L. & $"$ & $"$ & 3800 & $"$ & - & 1 & $\mathrm{~L}$ \\
\hline 12 & Tatlayoko L. & $"$ & $"$ & 2750 & $"$ & $\mathrm{~W}$ & 20 & $\mathrm{~L}$ \\
\hline 13 & Pass L. & $"$ & $"$ & 3150 & Luvisol & SW & 30 & $\mathrm{~L}$ \\
\hline 14 & Pass L. & $"$ & $"$ & 3175 & " & SW & 30 & $\mathbf{M}$ \\
\hline 15 & Bonaparte R. & $"$ & $"$ & 3115 & $"$ & - & 2 & M \\
\hline 16 & Bridesville & $"$ & $"$ & 4700 & $"$ & W & 5 & M \\
\hline 17 & Canoe Cr. & $"$ & $"$ & 3500 & Brunisol & - & 2 & $\mathbf{M}$ \\
\hline 18 & Canoe Cr. & $"$ & $"$ & 3900 & " & W & 5 & M \\
\hline 19 & Tunkwa L. & $"$ & $"$ & 4000 & Luvisol & WNW & 5 & $\mathrm{M}$ \\
\hline
\end{tabular}

Canopy indicated by M (medium), L (light), and 0 (zero).

above ground to make a combined sample of about $50 \mathrm{~g}$; the fresh material was placed in plastic bags which were sealed and stored at $-10^{\circ} \mathrm{C}$. Prior to analysis for miserotoxin, the freshfrozen plants were sorted and diced at $2^{\circ} \mathrm{C}, \quad 5$-g samples were pooled for duplicate dry weight determinations $\left(55^{\circ} \mathrm{C}, 48 \mathrm{hr}\right)$, and a 15 -g sample was tared for extraction and maintained at $-10^{\circ} \mathrm{C}$.

\section{Extraction of Miserotoxin}

The frozen, 15-g sample was extracted twice with $100 \mathrm{ml}$ boiling $80 \%$ ethanol in a Waring blender at high speed (two 1-min spins). The suspension was filtered on a Buchner funnel, the residue was washed with $250 \mathrm{ml}$ boiling $80 \%$ ethanol, and the volume of the filtrate was adjusted to 500.0 $\mathrm{ml}$. A $100-\mathrm{ml}$ aliquot was concentrated to dryness in a rotary evaporator, suspended in a minimum amount of hot water, filtered (Buchner funnel, 43 $\mathrm{mm}$ diam) through a bed of polyamide (Woelm) and Celite (1:3), and the filtrate was adjusted to $50.0 \mathrm{ml}$ (extract 1). Extract 1 is the starting point for the micro-isolation of miserotoxin on stratified thin-layer plates. The chromatographic and detection methods as well as the quantitative colorimetric procedures (coupling reaction between miserotoxin and diazotized paranitroaniline) have been described previously (Majak and Bose, 1974). Extraction of fresh material was preferable since the concentration of miserotoxin could be reduced significantly if timber milkvetch samples were initially oven dried and ground (Majak and Bose, 1974). The losses on drying may be partially attributed to the release and volatilization of the aglycone Since the extraction procedure was complete (as evidenced by thin-layer chromatographic checks of serial extractions) and since interspersed duplicate extractions yielded the same miserotoxin values, a single extraction of each sample was found to be sufficient. Extract 1, however, was chromatographed twice (two, 0.05-ml aliquots) and the miserotoxin band was eluted and quantified in duplicate. These duplicates differed by less than $5 \%$. The seasonal, peak miserotoxin concentration measured for a given plot was used as an index of toxicity and the various plots were compared on this basis.

\section{Results and Discussion}

The 19 experimental plots encompassed three plant zones: (1) rough fescue (Festuca scabrella); (2) Douglasfir (Pseudotsuga menziesii); (3) subalpine fir (Abies lasiocarpa); and four plant communities: (1) rough fescue eriogonum (Eriogonum heracleoides); (2) Douglasfir - rough fescue; (3) Douglasfir - pinegrass (Calamagrostis mubescens); (4) alpine big sagebrush (Artemisia tridentata ssp. vaseyana) pinegrass. Eighteen plots were situated in a parallelogram area $(100 \times 200$ miles) of the southern British Columbia interior and the remaining one (plot 12) was located in the Chilcotin district. The 19 sites represented a diversity of exposures, three soil orders, and elevations ranging from 2600 to $5700 \mathrm{ft}$ (Table 1).

\section{Fescue Grasslands (Plots 1 to 6)}

These sites, located on Black to Dark Brown Chernozemic soils, exem- plify the fescue grassland conditions of British Columbia and, with the exception of plot 5, they exhibited the maximum miserotoxin concentrations (5.8 to $7.3 \%$ ). The first experimental samples (May 4) were collected within a week of emergence and thus, a rapid synthesis of the toxin was reflected in the initial stages of growth (Fig. 1). The peak levels were associated with prebud and bud stages of growth followed by a decline occurring during bloom. Similar trends were described for plots 3 ("wet site") and 4 ("dry site") sampled during the summer of 1972 (Majak and Bose, 1974). Although plot 5 reveals a second peak at the prepod stage, this is not observed for either plots 1 and 2 or the "dry site" (see above). Sampling beyond the flower stage for the remaining sites $(3,4$, and 6$)$ was impossible due to extreme plant dessication. The short growing season for this group is attributed to the drought in the spring and summer of 1973. Precipitation for the month of July, for example, was the third lowest on record (0.09 inches) at the Kamloops airport, and the previous 15 months exhibited precipitation below the 30-year norm (Atmospheric Environmental Service, 1973). Excepting plot 5 , the peak miserotoxin concentrations occurred from the beginning of May to the beginning of June (1973), and there was no apparent relationship between these values and either slope or exposure. The pattern in plot 5 is enigmatic and whether it bears a relationship to plot 13 (see below) remains to be seen (i.e. plots 5 and 13 

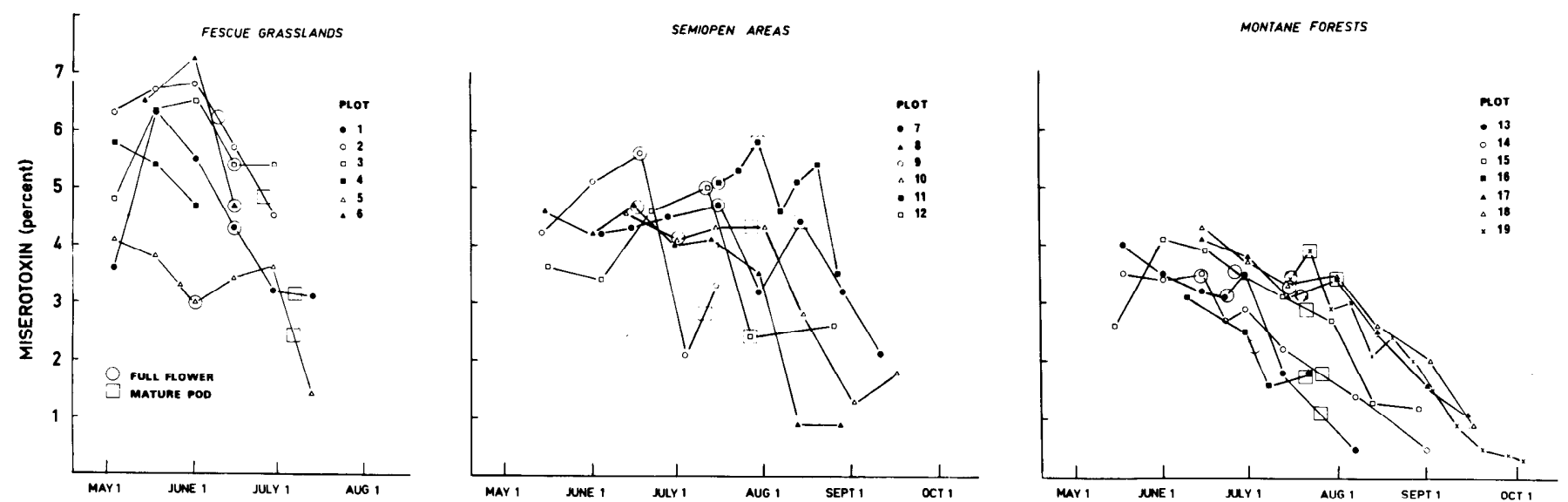

Fig. 1. Variation in miserotoxin concentration (percent dry weight) of timber milkvetch collected in 1973 and located in fescue grasslands (plots 1 to 6), semiopen areas (plots 7 to 12), and montane forests (plots 13 to 19).

exhibited lower miserotoxin levels than would be predicted).

\section{Montane Forests (Plots 13 to 19)}

These sites represent various successional levels of the Douglasfir climax forest (Tisdale and McLean, 1957): Douglas fir forest (plots 13 and 14); Douglasfir - lodgepole pine (Pinus contorta) (plots 15, 17, 18, and 19); Douglasfir - western larch (Larix occidentalis) (plot 16). The areas are characterized by medium canopy (with the exception of plot 13 which was a small opening in a Douglasfir forest) and either Brunisolic or Luvisolic soils.

Two basic trends are revealed by these groups (Fig. 1): plots 15, 17, 18, and 19, situated in typical lodgepole pine stands, exhibited peak concentrations (3.9 to $4.3 \%$ ) from the beginning of June to the beginning of August; plots 13,14 , and 16 , which are associated with Douglasfir stands, showed peak values (3.1 to $4.0 \%$ ) from the beginning of May to the beginning of July. Peak miserotoxin concentrations prior to flowering were evidenced, except for plot 19, where sampling was initiated at bloom and the earlier values were unknown. $\Lambda$ secondary peak was associated occasionally with the prepod (plots 13 and 14) and the pod stages (plots 17, 18, and 19). Evidence of regrowth may account for the undulating profile in plot 19; similar observations were made for plot 11 and the final sampling in plot 10 , which showed an increment in miserotoxin concentration.

Plots 13 and 14 , situated on the same slope, differed on the basis of elevation (3150 and $3175 \mathrm{ft}$ respectively) and canopy. The persistence of moisture in the covered forest area (plot 14) reflects the perseverance of timber milkvetch and the extension of the miserotoxin interval.

The trends indicate, therefore, that peak toxicity levels in the fescue grasslands are approximately twice as great as those in successional forests of the Douglasfir - pinegrass community. No direct relationship was observable between miserotoxin values and either elevation, exposure, slope, or latitude.

\section{Semiopen Areas (Plots 7 to 12)}

Trends are not readily apparent among these highly diversified sites which encompass two plant zones and three plant communities characterized by light canopies and mostly Brunisolic soils. Although plots 9 to 12 are found in the Douglasfir . pinegrass community they exhibit anomalous features in comparison to the normally-stocked forest areas (plots 13 to 19): plot 9, for example, was located in the open areas of a parkland; the western exposure of plot 10 , in a lodgepole stand, was adjacent to a marsh, and plot 11 was situated in a young lodgepole stand with a recent history of fire; plot 12 was found in an area of willow (Salix sp.) and Douglasfir reproduction with mature Douglasfir trees occurring at dispersed intervals. Plot 8 , on the other hand, was located in a Douglasfir - ponderosa pine (Pinus ponderosa) savannah; and plot 7 was unique, bordering the upper edge of a subalpine fir - Engelmann spruce (Picea engelmanni) forest. Thus, on the basis of available light, it can be hypothesized that plots 7 to 12 are characterized by conditions of intermediate light as compared to the fescue grasslands (abundant light) and the normally stocked montane forests (depressed light). Peak miserotoxin concentrations for plots 7 to $12(4.3$ to $5.8 \%$ ) are also intermediary to the high values for the fescue grasslands (5.8 to $7.3 \%$ ) and the low values for the normally stocked forests (3.1 to 4.3\%). Unlike the latter two groups, however, peak miserotoxin levels (Fig. 1) were associated with bloom (plots $7,8,9$, and 12) and pod stages (plots 7,10 , and 11) and, in this respect, the pattern resembles that of $A$. miser var. oblongifolius (Williams and Norris, 1969). Variety serotinus, however, exhibited miserotoxin fluctuations of greater magnitude.

\section{Conclusions}

The results of this survey conducted at 19 rangeland sites in British Columbia indicate that, with the exception of one site, the highest miserotoxin concentrations were attained in the fescue grasslands during the spring. Concomitantly, the medium-canopied Douglasfir - lodgepole pine forests revealed significantly lower maxima while exposed forest areas exhibited intermediate peaks. The corollary suggests, therefore, that timber milkvetch poisoning could be controlled, in part, by avoiding the fescue grasslands in spring and minimizing grazing in exposed forest areas. The incidence of poisoning, however, is also a function of the rates of timber milkvetch ingestion and toxin absorption. A Hereford steer (479 lb), for example, can dic with 4.5 hours after the direct administration (by stomach pump) of $2.24 \mathrm{lb}$ of dried timber milkvetch containing $2.1 \%$ misero- 
toxin (Williams et al., 1969). Thus, affection frequency is related also to timber milkvetch density and range quality. Well-managed "high toxin" ranges could conceivably result in fewer cases of poisoning than over grazed "low toxin" areas which were depleted of grasses, thus increasing the relative proportion of timber milkvetch.

\section{Literature Cited}

Atmospheric. Environmental Service. 1973. Monthly meteorological summary. For the month of July 1973 at Kamloops Airport, B.C., Atm. Environ. Serv., Dep. Environ. Can.

Barneby, R. C. 1956. Puguillus Astragalorum XVIII: Miscellaneous novelties and reappraisals. Amer. Midland Natur. 55: 477-503.

British Columbia Dep. of Agriculture. 1967. Timber milkvetch survey summary. 3 p.

Bruce, E. A. 1927. Astraglaus campestris and other stock poisoning plants of British Columbia. Canada Dep. Agr. Bull. 88.
Canada Soil Survey Committee. 1970. The system of soil survey for Canada. Queen's Printer, Ottawa.

Hahn, C. J. 1970. 3-nitro-1-propanol, A toxic compound in timber milkvetch (Astragalus miser). Agr. Exp. Sta. Univ. ofWyoming Sci. Monog. 20.

Hall, K., and V. C. Brink. 1971. The evaluation of nitrogenous fertilization of B. C. rangelands. Abstr. Agr. Inst. Can., 51 st Ann. Meeting, Lethbridge, Alberta.

MacDonald, M. A. 1952. Timber milkvetch poisoning in British Columbia ranges. $\mathrm{J}$. Range Manage. 5:16-21.

Majak, W., and R. J. Bose. 1974. Chromatographic methods for the isolation of miserotoxin and for the detection of aliphatic nitro compounds. Phytochemistry 13:1005-1010.

Mosher, G. A., C. R. Krishnamurti, and W. D. Kitts. 1971. Physiological effects of timber milkvetch, Astragalus miser var. serotinus, on sheep. Can. J. Anim. Sci. $51: 465-474$.

Nicholson, H. H. 1963. The treatment of timber milkvetch poisoning among cattle and sheep. Can J. Anim. Sci. 43:237-240.

Norris. F. A. 1970. Constituents and toxic principle of Astragalus miser. Ph D thesis, Utah State University.

Stermitz, F. R., F. A. Norris, and M. C. Williams. 1969. Miserotoxin, a new naturally-occurring nitro compound. J. Amer. Chem. Soc. 91:4599.

Stermitiz, F. R., W. T. Lowry, F. A. Norris, F. A. Buckeridge, and M. C. Williams. 1972. Aliphatic nitro compounds from Astragalus species. Phytochemistry 11:1117-1124.

Tisdale, E. W., and A. McLean. 1957. The Douglas fir zone of southern British Columbia. Ecol. Monogr. 27:247-266.

Williams, M. C. 1970. Detoxification of timber milkvetch by 2, 4, 5-T and Silvex. J. Range Manage. 23:400-402.

Williams, M. C., and F. A. Norris. 1969. Distribution of miserotoxin in varieities of Astragalus miser Dougl. ex Hook. Weed Sci. 17:236-238.

Williams, M. C., K. R. Van Kampen, and F. A. Norris. 1969. Timber milkvetch poisoning in chickens, rabbits and cattle. Amer. J. Vet Res. 30:2185-2190.

Williams, M. C., F. A. Norris, and K. R. Van Kampen. 1970. Metabolism of miserotoxin to 3-nitro-1-propanol in bovine and ovine ruminal fluids. Amer. J. Vet. Res. 31:259-262. 